\title{
Dialectical Linguistics of Public Signs in Sidoarjo Regency: An Approach in Ecolinguistics Study
}

\author{
Ferina Kumala Dewi \\ Universitas Diponegoro, Semarang, Indonesia \\ Email: ferinakd@gmail.com
}

status and economy in a society in Sidoarjo Regency.

\begin{tabular}{l}
\hline Available Online: \\
\hline http://www.jurnal.unublitar.ac.id \\
/index.php/briliant
\end{tabular}

History of the Article:

Received on 8 July 2020

Accepted on 27 August 2020

Published on 31 August 2020

Page 549-550

\begin{tabular}{l}
\hline Keywords: \\
\hline $\begin{array}{l}\text { Ideologica; Sociological; } \\
\text { Biological Background }\end{array}$ \\
\hline DOI: \\
\hline http://dx.doi.org/10.28926/brilian \\
t.v3i4.509 \\
\hline
\end{tabular}

Abstrak: This study aims to reveal the ideological, sociological and biological background of the public signs. This study is focused on public sign in Sidoarjo Regency. In this case, I collected data in several public areas namely International airport, bus station, train station, housing, school, park, and cemetery on 18 subdistricts in Sidoarjo regency in 2019. In total, there are 65 data, which are taken purposively to show ideological, sociological, and biological dimension. There are three conclusions in this study. First, in Biological background, several morphemes that reflected biological condition in either biotic or abiotic components are found in aquaculture area, park, cemetery and housing. Second, the ideological background, the public sign that contained belief, myth, and paradigm in a society are found in housing, train station, park, river, gas station, cemetery, mosque and factory. Third, in sociological dimension, the morphemes and phrases contain various job, political system,

\section{INTRODUCTION}

Sidoarjo Regency is regency in East Java, Indonesia. There are 18 sub districts in Sidoarjo Regency. Those are Balongbendo, Buduran, Candi, Gedangan, Jabon, Krembung, Krian, Porong, Prambon, Sedati, Sidoarjo, Sukodono, Taman, Tanggulangin, Tarik, Tulangan, Waru, and Wonoayu. Sidoarjo Regency is bordered by Surabaya City and Gresik Regency in the north, Pasuruan Regency in the south, Mojokerto Regency in the west, and Madura Strait in the east.

Based on the data from Government of Sidoarjo Regency in 2019, hydrologically, Sidoarjo Regency is located between two rivers, namely Brantas river and Porong river which are branch of Brantas river from its upstream in Malang regency. Topographically, The eastern region is an aquaculture area which is a Delta plain with an altitude between 0 to 25 meters, height 0 to 3 meters, with an area of $19.000 \mathrm{Ha}$, covering $29.99 \%$. The center region is a residential area, trade, and government which cover $40.81 \%$ of freshwater region with an altitude of 3 to 10 meters above sea level. The $29.20 \%$ in the western region is an agricultural area with a height of 10 to 25 meters above sea level.

As cited from the website of the Government of Sidoarjo Regency, fisheries, Industries, and services are the main economic sectors of Sidoarjo. The Madura strait in the East is a fishery producing area including Fish, Shrimp, and 
Crab. The Industrial sector is growing rapidly because there are 978 factories in Sidoarjo. In the services sector, especially transportation, there are International airport, 10 train stations, and bus station.

Refer to the data of the Government of Sidoarjo Regency, the highest to the lowest resident population are Waru, Taman, Sidoarjo, Candi, Krian, Gedangan, Sukodono, Sedati, Tanggulangin, Buduran, Tulangan, Porong, Wonoayu, Prambon, Balongbendo, Krembung, and Tarik. Each sub district is divided into several public places namely school, housing, cemetery, and market. The difference of economy, hydrology, and topography make people have different habit and characteristic in each place. One of the differences on each place is the language used, especially in the public sign.

A public sign is a kind of imperative clause because it states commands, warning, and request. Imperative clauses are command that tell the reader to take action, and their tone can vary from demanding and strict to polite and inviting. Most imperative clauses have the base form of the verb, and lack of subject, modal, and markers for tense and aspect (Myers, 1994: 46-52). However, other imperative clauses are in the form of statement and question.

In Sidoarjo Regency, public signs are found in some public areas namely parks, schools, bus stations, train stations, International airport, cemeteries, and housing. These public signs can vary in the form of clause and opt of word depend on where the public signs are exist. For example, Jabon Sub district is the eastern region which is an aquaculture area, so the words in the public signs are about fisheries.

According to Kurniawati (2018: 3), the public signs are divided into conventional and unconventional sign. Conventional sign is in the form of imperative which has base verb and lack of subject. In conventional sign, there is official rule arranged by government reflected in regional regulation. The chosen words in conventional signs are in formal form. The unconventional sign is in the form of statement and question. The rule and punishment in the unconventional signs are arranged by society where the public signs are exist. The rule and punishment can be varied based on the society. The chosen words in the unconventional signs are in informal form.

The chosen of informal words in unconventional signs are assumed as rude and impolite because the signs are inappropriate with the norm and value in a society. In this condition, there must be a reason behind producing such word. There is a relation found in this chaos. This relation is a contribution of language, ecology and society. As cited from Steffensen (2007: 3), this relation called as Dialectical Linguistics. An approach of Dialectical Linguistics is expected to reveal the background behind producing a text. Because, social praxis may be relate to a language or vice versa.

In Dialectical linguistic, an unconventional sign can be reviewed in three perspectives. Those are biological, ideological and sociological background. In biological, human are oriented to be a part of living system in ecosystem. So, a language is influenced by an interrelationship between human and environment. This environment refers to topographic and geographical condition, biotic and abiotic components, or even climate system. Ideological background refers to belief, dogma, value, and norm within a society. So, we have to realize that an ideological background in one society may be inappropriate on the other society. 
The last background is sociological background. It indicates a relationship between human as social beings. A social being denotes to what social status of human based on their distinction in education, economy, job, position, and culture.

According to phenomena mentioned above, public signs in Sidoarjo regency would be analyzed in Ecolinguistics study. This analysis may reveal biological, ideological, and sociological backgrounds reflected in public signs. In biological background, there are several words that show the characteristic of topographic and geographical condition, biotic and abiotic components on each sub district in Sidoarjo. In ideological background, there are various value and norm within a society on each sub district in Sidoarjo. In sociological background, there are various education level, job and economy in Sidoarjo.

There are six studies in ecolinguistics from 2015 until 2018. These five studies are concern in discovering some lexicon in conservation news text, Dawan community, eco agriculture lexicon in Angkola/Mandailing Language, lexicon of folklore in Toba Lake, lexicon of fauna in Sundanese community and lexicon Tukad Badung in Bali. There are four studies concern in sign and text in 2017 and 2018. In these four studies, the objects of analysis are no littering signs in Yogyakarta and google, texts on Papuan online mass media, green discourses in Mass Media, and environmental slogans from www.pribahasaindonesia.com. From ten studies mentioned before, a study of public signs in Sidoarjo Regency with Ecolinguistics study is the novelty.

The results of this study will contribute to enrich analysis in Ecolinguistics study. Although, unconventional sign can be analyzed with other theory, but unconventional sign will be revealed in depth with Ecolinguistics study. This study of Ecolinguistics became popular due to discourse in concerning environment arose. The characteristic of society in culture, place, and norm would be reflected in the public signs.

This study is focused on public sign in Sidoarjo regency. Those are conventional and unconventional sign in public area namely International airport, bus station, train station, housing, school, park, and cemetery. The data are clauses in the public sign. They are taken from 18 sub district in Sidoarjo regency. Then, I analyzed the data using dialectical Ecolinguistic theory by Bundsgaard and Sune Steffensen. This analysis may reveal biological, ideological, and sociological backgrounds reflected in public signs.

Ecolinguistics or language ecology is a new paradigm in linguistics research that study a language related to ecological and environment problems pioneered by Einar Haugen. This theory is a new trend in linguistic research to facilitate not only social factor but also ecological context in a society. Because, we live in the world and we have a role in shaping the world through the language we used (Fill: 2017).

In the late 1960s, Bang and Door contributed in developing a new theory that is Dialectical Linguistics. In this theory, we examine some factors that influence our language and our interaction. We investigate the relation of ecology, society, and language. A language in a community can be seen from three interrelations of ideological, biological and sociological (Steffensen, 2007: 1). Then, these three interrelations are applied in four models of analysis. Those are

542 BRILIANT: Jurnal Riset dan Konseptual Volume 5 Number 3, August 2020 
dialogue model, semantic matrix model, triple model of reference, and core contradiction of the social praxes.

The dialogue model can be seen from the figure 1.1 as proposed by Bang and Door.

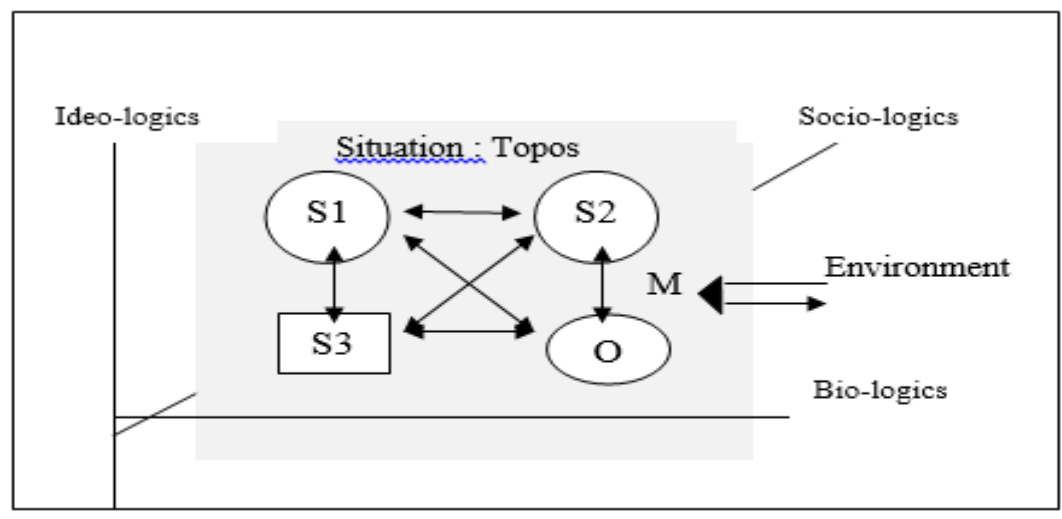

Figure 1.1 Dialogue Model

In figure 1.1, $\mathrm{S}_{1}$ and $\mathrm{S}_{2}$ represent the position of speaker and addressee. The symbol $\mathrm{O}$ refers to an object that being discussed in a dialogue. The $\mathrm{S}_{3}$ is the component of sociocultural constituent. The affairs of four components are happen in TOPOS reflected in biological, sociological, and ideological dimension. The situation of these four components are represented in the ' $\leftrightarrow$ arrow as dialectical arrows. In this figure, it is simply conclude that a situation of dialogical background in an utterance or a sentence is related to interpretation or meaning in dialogue model.

In figure 1.2 shown that in analyzing the relation of text and context, we can see from this triple model of reference.

\begin{tabular}{|c|c|c|c|c|}
\hline $\begin{array}{l}\text { Dimension } \\
\text { of reference }\end{array}$ & $\begin{array}{c}\text { Dominating } \\
\text { reference }\end{array}$ & \multicolumn{3}{|c|}{$\begin{array}{l}\text { Reference } \\
\text { to }\end{array}$} \\
\hline Lexical & Inter-textual & COtext & $\begin{array}{l}\text { Social \& } \\
\text { Individual }\end{array}$ & $\begin{array}{l}\text { Lexicon \& } \\
\text { Grammar }\end{array}$ \\
\hline \multirow[t]{2}{*}{ Anaphoric } & Intra-textual & INtext & $\begin{array}{l}\text { Cataphoric (forward) } \\
\text { Anaphoric (backward) } \\
\text { Symphoric (simultaneous) }\end{array}$ & \\
\hline & $\begin{array}{l}\text { Extra- } \\
\text { textual }\end{array}$ & CONtext & $\begin{array}{l}\text { Context of producer(s) } \\
\text { Context of the communicator(s) } \\
\text { Context of the consumer(s) } \\
\text { Derived contexts }\end{array}$ & $\begin{array}{l}\text { Person } \\
\text { Time } \\
\text { Place } \\
\text { Logics }\end{array}$ \\
\hline
\end{tabular}

Figure 1.2 Triple Model of Reference

Inter textual is related to a relation of meaning and interpretation. But, the meaning and interpretation are individually different. Intra textual is the relation 
between text production in the dialogue or written text. The relation of extra textual indicates a language to a reality condition because a language is tied to a kind situation in time and place.

In figure 1.3, in dialectical point of view, the analysis of actual dialogue concern in four components namely, social sense, individual meaning, personal significance, and social import. Social sense is a shared knowledge between speaker and addressee in a community. Individual meaning refers to personal interpretation that indicates personality and social identity. Social import is a specific context, such as an office, a hospital, a congress, or a mall. Personal significance represents a unique representation from person in a dialogue.

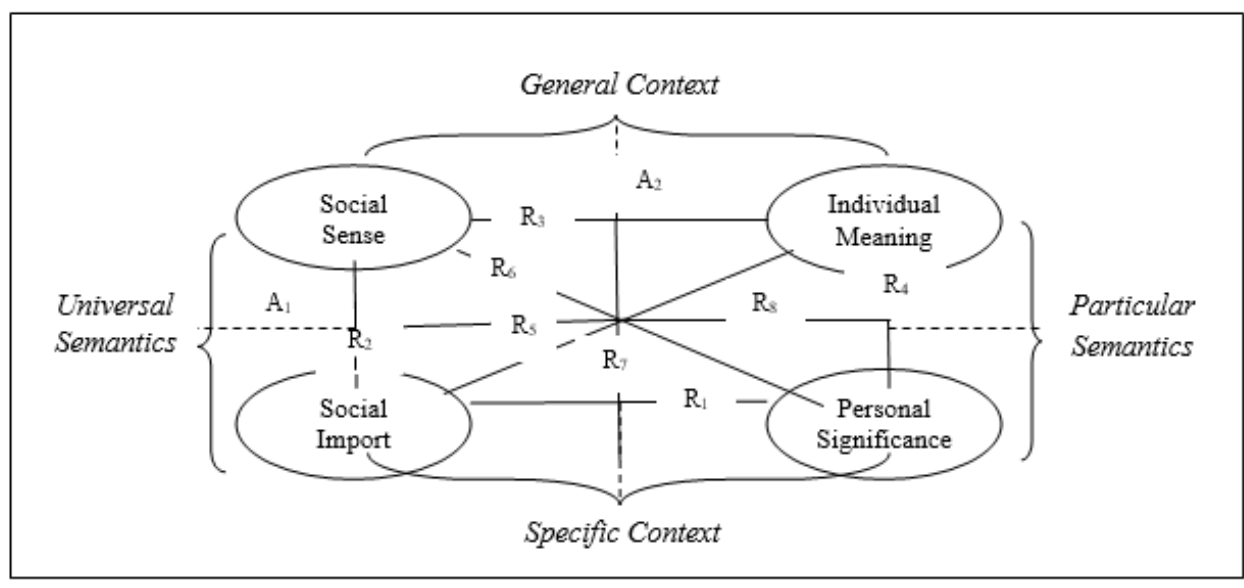

Figure 1.3 Semantic matrix

Figure 1.4 is the core contradiction of the social praxis. In analyzing a text or language product, the relation of situation reveals the understanding of social praxis. In this condition, a language would be seen in three dimensional backgrounds. Those are ideological background, sociological background, and biological background. A language can be developed and extinct in human's life. A language is not only influence but also influenced by the society.

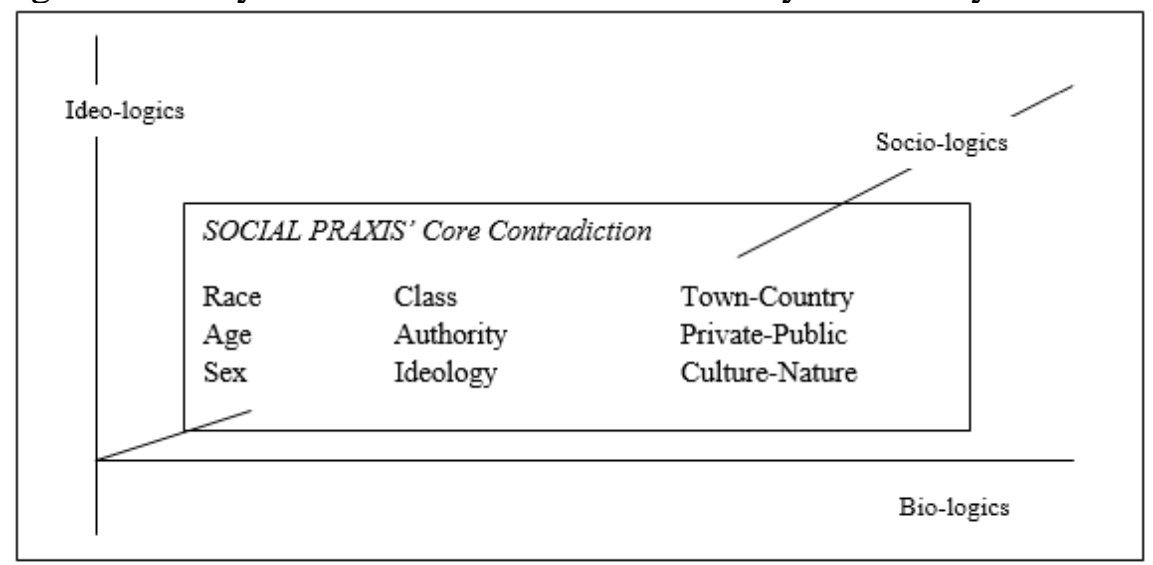

Figure 1.4 Core contradictions of the social praxis

\section{METHOD}

This study is descriptive qualitative. Descriptive study means to describe a situation or area of interest factually and accurately (Isaac \& Michael, 1995: 43). The method of collecting data was observation with non- 
participant observation continued with documentation technique by taking a photo.

According to Sudaryanto (1993: 123), in the non participant technique, there is no involvement of the researcher in the dialogue. In this case, I collected data in several public area namely International airport, bus station, train station, housing, school, park, and cemetery on 18 subdistrict in Sidoarjo regency in 2019. In total, there are 65 data are taken purposively to show ideological, sociological, and biological dimension.

The data are analyzed with Identity method because there are relation between language and biological, sociological and ideological backgrounds reflected in the data. This identity method is kind of referential identity method because the references are biological, sociological and ideological background.

\section{FINDING}

Sidoarjo Regency is bordered by Surabaya City and Gresik Regency in the north, Pasuruan Regency in the south, Madura Strait in the east, and Mojokerto Regency in the west. Hydrologically, Sidoarjo Regency is located between two rivers, namely Brantas River and Porong River which are branch of Brantas river from its upstream in Malang regency. Topographically, the eastern region is an aquaculture area, the center region is a residential area, trade, government, and in the western region is an agricultural area. The difference in hydrology and topography becomes a characteristic on each place at public sign.

1. The data about biological background are presented in the table below.

\begin{tabular}{|c|c|c|}
\hline No & Public sign & Morpheme and Phrase \\
\hline 1. & Dilarang membuang kucing dll disini! & Kucing \\
\hline 2. & Dilarang Menginjak Rumput dan Tanaman & $\begin{array}{l}\text {-Rumput } \\
\text {-Tanaman }\end{array}$ \\
\hline 3. & Dilarang memetik bunga & Bunga \\
\hline 4. & Dilarang membuang sampah di lahan ini & Lahan \\
\hline 5. & $\begin{array}{l}\text { Perhatian } \\
\text { Dilarang keras mengijing/mengeris \& } \\
\text { membuang gragal di lokasi makam }\end{array}$ & Gragal \\
\hline 6. & Dilarang menggali tanah & Tanah \\
\hline 7. & Dilarang bercocok tanam & Tanam \\
\hline 8. & $\begin{array}{l}\text { Dilarang mencari rumput disini ada } \\
\text { tanaman rumput gajah }\end{array}$ & Tanaman rumput gajah \\
\hline 9. & Dilarang mancing jaring dll lebon nila & $\begin{array}{l}\text {-Lebon } \\
\text {-Nila }\end{array}$ \\
\hline 10. & $\begin{array}{l}\text { Setiap orang dan / atau badan "Dilarang" } \\
\text { mempergunakan jalan, trotoar, jalur hijau, } \\
\text { dan taman selain untuk diperuntukkannya }\end{array}$ & Taman \\
\hline 11. & $\begin{array}{l}\text { Dilarang!!! membuang sampah dan atau } \\
\text { hewan sepanjang jalan bougenville }\end{array}$ & Hewan \\
\hline 12. & Dilarang buang air besar di sungai!!! & Sungai \\
\hline 13. & Stop! buang sampah di sungai/selokan & Selokan \\
\hline 14. & $\begin{array}{l}\text { Dilarang!! Memakai dan menggarap tanah } \\
\text { tanpa izin yang berhak atas kuasanya }\end{array}$ & Tanah \\
\hline
\end{tabular}




\begin{tabular}{|c|c|c|}
\hline & $\begin{array}{l}\text { pasal } 165 \mathrm{KUH} \text { pidana Pasal } 6 \text { UU No } 51 \\
\text { PRP tahun } 1960 \mathrm{KUH} \text { Pidana }\end{array}$ & \\
\hline 15. & Dilarang membawa binatang & Binatang \\
\hline 16. & $\begin{array}{l}\text { Perhatian Barang siapa membuang } \\
\text { sampah di area ini } \\
\text { 1. Diancam Pidana Kurungan } 3 \text { bulan } \\
\text { 2. Denda Rp 50.000.000 Pasal } 63 \\
\text { PERDA No: } 6 / \text { TH } 2012\end{array}$ & Area \\
\hline 17. & Dilarang berjualan disepanjang jalan ini & Jalan \\
\hline 18. & $\begin{array}{l}\text { Dilarang mendirikan bangunan apapun } \\
\text { diatas sepadan/saluran Peraturan Daerah } \\
\text { Kabupaten Sidoarjo Nomor } 3 \text { Tahun } 2014 \\
\text { tentang irigasi }\end{array}$ & $\begin{array}{l}\text {-Sepadan } \\
\text {-Saluran }\end{array}$ \\
\hline 19. & $\begin{array}{l}\text { Jangan wariskan sungai \& lingkungan } \\
\text { penuh dengan sampah pada anak \& cucu } \\
\text { kita }\end{array}$ & $\begin{array}{l}- \text { Anak } \\
\text {-Cucu }\end{array}$ \\
\hline 20. & $\begin{array}{l}\text { Dilarang keras Mandi/Berenang Mancing } \\
\text { di Area ini Kedalaman } 4 \text { meter }\end{array}$ & Kedalaman \\
\hline 21. & Pelan pelan banyak anak mengaji & Anak \\
\hline
\end{tabular}

2.1 The data in Biological background

2. In ideological dimension, the morpheme and phrase contain a myth, belief, and paradigm in a society are presented in table 2.2

\begin{tabular}{|c|c|c|}
\hline No & Public Sign & Morpheme and Phrase \\
\hline 1. & Dilarang membawa senjata jenis apapun & Senjata \\
\hline 2. & $\begin{array}{l}\text { Dilarang membawa narkotika, } \\
\text { psikotropika dan zat adiktif lainnya }\end{array}$ & $\begin{array}{l}\text {-Narkotika } \\
\text {-psikotropika } \\
\text {-zat adiktif }\end{array}$ \\
\hline 3. & Dilarang membawa benda berbau tajam & Benda berbau tajam \\
\hline 4. & $\begin{array}{l}\text { Dilarang melakukan tindakan diluar } \\
\text { norma-norma kesopanan/kesantunan dan } \\
\text { tindakan asusila lainnya. }\end{array}$ & $\begin{array}{l}\text {-Tindakan asusila } \\
\text {-Tindakan diluar norma- } \\
\text { norma kesopanan/kesantunan }\end{array}$ \\
\hline 5. & Dilarang keras merokok & Merokok \\
\hline 6. & Dilarang menggunakan telepon selular & Telepon Selular \\
\hline 7. & Matikan mesin saat mengisi bbm & Matikan mesin \\
\hline 8. & $\begin{array}{l}\text { Mohon maaf bagi wanita haid/datang } \\
\text { bulan haram masuk masjid }\end{array}$ & Haram \\
\hline 9. & Masuk makam kendaraan harus turun & Harus turun \\
\hline & $\begin{array}{l}\text { Semua warga yang mempunyai ahli waris } \\
\text { di makam islam desa buduran dilarang } \\
\text { mengeris/kejing di dalam makam. }\end{array}$ & $\begin{array}{l}\text {-Mengeris } \\
\text {-Kejing }\end{array}$ \\
\hline 10. & Dilarang buang air besar di sungai!!! & Buang air besar \\
\hline 12. & $\begin{array}{l}\text { Dilarang membuang sampah di } \\
\text { area/sepanjang jalan ini seluruh warga } \\
\text { RT.22 Ndungo: Mugo mugo seng buang } \\
\text { sampah nek kene uripe tambah soro }\end{array}$ & Ndungo \\
\hline 13. & Masjid tempat untuk ibadah mohon tidak & Tolak politisasi \\
\hline
\end{tabular}

546 BRILIANT: Jurnal Riset dan Konseptual Volume 5 Number 3, August 2020 


\begin{tabular}{|c|c|c|}
\hline & $\begin{array}{l}\text { digunakan untuk kepentingan politik tolak } \\
\text { politisasi masjid }\end{array}$ & \\
\hline 14. & $\begin{array}{l}\text { Yang buang sampah disini nantikan azab } \\
\text { ilahi Amin Ya Allah }\end{array}$ & Azab ilahi \\
\hline 15. & $\begin{array}{l}\text { Dilarang buang sampah disini kecuali } \\
\text { anjing }\end{array}$ & Anjing \\
\hline 16 & Dilarang kencing disini kecuali anjing & Kencing \\
\hline 17 & Anda memasuki kawasan berjilbab & Kawasan berjilbab \\
\hline 18. & Dilarang mengkijing/menyemen makam & $\begin{array}{l}\text {-Mengkijing } \\
\text {-Menyemen }\end{array}$ \\
\hline 19. & Sepeda dilarang masuk di area makam & Sepeda \\
\hline 20. & $\begin{array}{l}\text { Awas Pak/Buk Sampahnya bisa pulang } \\
\text { kerumah lo gak percaya buktikan sekarang }\end{array}$ & Gak percaya \\
\hline 21. & $\begin{array}{l}\text { Dilarang ngebut di dalam kawasan } \\
\text { perusahaan }\end{array}$ & Ngebut \\
\hline 22. & $\begin{array}{l}\text { Perhatian!!! Kecepatan maksimal } \\
20 \mathrm{~km} / \mathrm{jam}\end{array}$ & Kecepatan Maksimal \\
\hline 23. & $\begin{array}{l}\text { Dilarang buang sampah di area sungai } \\
\text { kecuali anjing 'cokjancok' }\end{array}$ & Cok jancok \\
\hline 24. & Dilarang untuk belajar mobil & Mobil \\
\hline
\end{tabular}

2.2 The data in Ideological background

3. In sociological dimension, the morphemes and phrases that contain various job, political system, status and economy in a society are presented in table 2.3.

\begin{tabular}{|c|c|c|}
\hline No & Public sign & Morpheme, Phrase \\
\hline 1. & $\begin{array}{l}\text { Jangan buang sampah disekitar jalan ini } \\
\text { denda } 500 \text { rb/penjara } 6 \text { bulan }\end{array}$ & Denda 500rb/penjara 6 bulan \\
\hline 2. & $\begin{array}{l}\text { Dilarang masuk pemulung } \\
\text { pengemis, dan pencari } \\
\text { dilingkungan } \text { sumbangan } \\
\text { Sukodono }\end{array}$ & 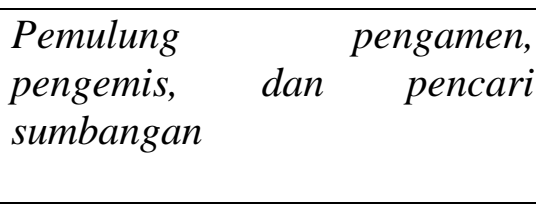 \\
\hline 3. & $\begin{array}{l}\text { Dilarang mendirikan bangunan di area } \\
\text { lahan ini. Bila melanggar, akan berurusan } \\
\text { dengan yang berwajib. }\end{array}$ & $\begin{array}{l}\text { Berurusan dengan yang } \\
\text { berwajib. }\end{array}$ \\
\hline 4. & $\begin{array}{l}\text { Pengamen, pemulung, rombeng, dilarang } \\
\text { masuk }\end{array}$ & $\begin{array}{l}\text {-Pengamen } \\
\text {-Pemulung } \\
\text {-Rombeng }\end{array}$ \\
\hline 5. & 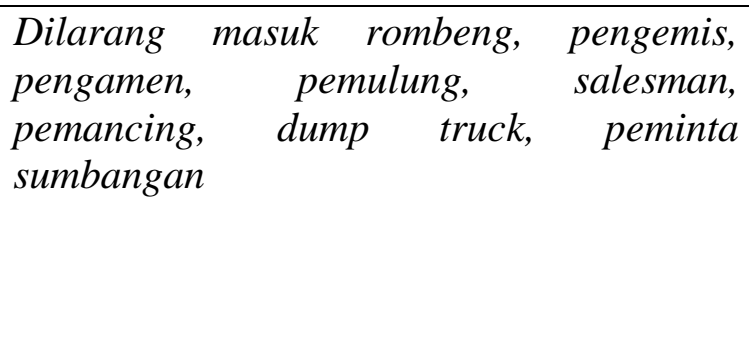 & $\begin{array}{l}\text {-Rombeng } \\
\text {-Pengemis } \\
\text {-Pengamen } \\
\text {-Pemulung } \\
\text {-Salesman } \\
\text {-Pemancing } \\
\text {-Peminta sumbangan }\end{array}$ \\
\hline 6. & $\begin{array}{l}\text { Perhatian! Selain warga } R W 01 \text { Dilarang } \\
\text { buang sampah ditempat ini dilanggar } \\
\text { denda } R p 250.000\end{array}$ & Denda $R p 250.000$ \\
\hline
\end{tabular}




\begin{tabular}{|c|c|c|}
\hline 7. & $\begin{array}{l}\text { Dilarang merokok di areal SPBU } \\
\text { Ketangkap basah merokok di areal SPBU } \\
\text { didenda Rp } 50.000\end{array}$ & Denda Rp 50.000 \\
\hline 8. & $\begin{array}{l}\text { Perhatian! jangan berenang di } \\
\text { DAM/Sungai Berbahaya! Peraturan } \\
\text { Daerah Kabupaten Sidoarjo Nomor } 3 \\
\text { Tahun } 2004 \text { Tentang Irigasi }\end{array}$ & $\begin{array}{l}\text { Peraturan Daerah Kabupaten } \\
\text { Sidoarjo Nomor } 3 \text { Tahun } 2004 \\
\text { Tentang Irigasi }\end{array}$ \\
\hline 9. & $\begin{array}{l}\text { Dilarang berjualan di area sekolah SMPN } \\
2 \text { Gedangan }\end{array}$ & Berjualan \\
\hline 10. & $\begin{array}{l}\text { Dilarang!! Memakai dan menggarap tanah } \\
\text { tanpa izin yang berhak atas kuasanya } \\
\text { pasal } 165 \mathrm{KUH} \text { pidana Pasal } 6 \text { UU No } 51 \\
\text { PRP tahun } 1960 \mathrm{KUH} \text { Pidana }\end{array}$ & $\begin{array}{l}\text { Pasal } 165 \text { KUH pidana Pasal } \\
6 \text { UU No } 51 \text { PRP tahun } 1960 \\
\text { KUH Pidana }\end{array}$ \\
\hline 11. & $\begin{array}{l}\text { Dilarang mendirikan bangunan apapun } \\
\text { diatas sepadan/saluran Peraturan Daerah } \\
\text { Kabupaten Sidoarjo Nomor } 3 \text { Tahun } 2014 \\
\text { tentang irigasi }\end{array}$ & $\begin{array}{l}\text { Peraturan Daerah Kabupaten } \\
\text { Sidoarjo Nomor } 3 \text { Tahun } 2014 \\
\text { tentang irigasi }\end{array}$ \\
\hline 12. & $\begin{array}{l}\text { Dilarang buang sampah!! Disepanjang } \\
\text { jalan ini melanggar peraturan desa No. 05 } \\
\text { Tahun } 2015 \text { denda sebesar } 5 \text { juta atau } \\
\text { pidana }\end{array}$ & $\begin{array}{l}\text { Peraturan desa No. 05 Tahun } \\
2015 \text { denda sebesar } 5 \text { juta } \\
\text { atau pidana }\end{array}$ \\
\hline 13. & $\begin{array}{l}\text { Dilarang membuang sampah di } \\
\text { area/sepanjang jalan ini seluruh warga } \\
\text { RT.22 Ndungo: Mugo mugo seng buang } \\
\text { sampah nek kene uripe tambah soro }\end{array}$ & Warga RT.22 \\
\hline 14. & $\begin{array}{l}\text { Dilarang keras membuang sampah } \\
\text { disepanjang jalan ini apabila kedapatan } \\
\text { membuang sampah disepanjang jalan ini } \\
\text { didenda } R p 500.000\end{array}$ & Denda $R p 500.000$ \\
\hline 15. & $\begin{array}{l}\text { Perhatian Barang siapa membuang } \\
\text { sampah di area ini } \\
\text { 1. Diancam Pidana Kurungan } 3 \text { bulan } \\
\text { 2. Denda Rp } 50.000 .000 \text { Pasal } 63 \\
\text { PERDA No: } 6 / T H 2012\end{array}$ & $\begin{array}{l}\text {-Pidana Kurungan } 3 \text { bulan } \\
\text {-Denda Rp 50.000.000 Pasal } \\
63 \text { PERDA No: 6/TH } 2012\end{array}$ \\
\hline 16. & $\begin{array}{l}\text { Setiap orang dan / atau badan "Dilarang" } \\
\text { mempergunakan jalan, trotoar, jalur hijau, } \\
\text { dan taman selain untuk diperuntukkannya } \\
\text { berdasarkan PERDA } 10 \text { tahun } 2013 \\
\text { tentang ketertiban umum dan ketentraman } \\
\text { masyarakat. }\end{array}$ & $\begin{array}{l}\text { PERDA } 10 \text { tahun } 2013 \text { tentang } \\
\text { ketertiban umum dan } \\
\text { ketentraman masyarakat }\end{array}$ \\
\hline 17. & $\begin{array}{l}\text { Dilarang masuk ataupun parkir selain } \\
\text { petugas }\end{array}$ & Selain petugas \\
\hline 18. & $\begin{array}{l}\text { Pelajar/siswa berseragam sekolah } \\
\text { dilarang berada di Area Alun-alun tanpa } \\
\text { seijin pihak sekolah. }\end{array}$ & Seijin pihak sekolah. \\
\hline 19. & $\begin{array}{l}\text { Selain warga } R T \text { O6 } R W 01 \text { Dilarang } \\
\text { buang sampah disini! Melanggar akan }\end{array}$ & Denda sebesar $R p 200.000$ \\
\hline
\end{tabular}

548 BRILIANT: Jurnal Riset dan Konseptual Volume 5 Number 3, August 2020 


\begin{tabular}{l|l|l|}
\hline & dikenakan denda sebesar Rp 200.000 & \\
\hline 20. & Dilarang masuk sebelum jam 07.00 WIB & Sebelum jam 07.00 \\
DISCUSSION & 2.3 The data in sociological background
\end{tabular}

In Biological background, there are several morphemes reflected biological condition. The biological condition is reflected in either biotic or abiotic components. The data are found in aquaculture area, park, cemetery and housing. In the table 2.1, the biotic components are living things, namely Kucing, Rumput, Tanaman, Bunga, Tanaman Rumput Gajah, Lebon, Nila, Hewan, Binatang, Anak, and Cucu. The abiotic components are non living things, namely Lahan, Gragal, Tanah, Taman, Sungai, Selokan, Area, Jalan Sepadan, and Saluran.

In the ideological background, there are morphemes and phrases that show belief, myth, and paradigm in a society. The morphemes and phrases are Senjata, Narkotika, Psikotropika, Zat Adiktif, Benda Berbau Tajam, Tindakan Asusila, Tindakan Diluar Norma-Norma Kesopanan/Kesantunan, Merokok, Telepon Selular, Matikan Mesin, Haram, Harus Turun, Mengemis, Tolak Politisasi, Azab Ilahi, Ndungo, Kawasan Berjilbab, Kejing, Mengeris, Ga Percaya, Ngebut, Kecepatan Maksimal, Mobil, Sepeda, Kencing, Buang Air Besar, and Cok Jancok.

The public signs in table 2.2 are found in housing, train station, park, river, gas station, cemetery, mosque and factory. For example, the morphemes mengkijing and menyemen in the public sign "Dilarang mengkijing/menyemen makam" are found in Buduran, Sedati, and Sidoarjo sub district. According to their belief, every grave should have same level in height. So, they are not allowed to build any permanent thing on the top of the grave.

In sociological dimension, the morphemes and phrases contain various job, political system, status and economy in a society. The morphemes and phrases denoted to a job and status are Pemulung, Pengamen, Pengemis, Pencari Sumbangan, Rombeng, Salesman, Pemancing, Berjualan, Warga RT 22, Selain Petugas, and Seizin Pihak Sekolah. The morphemes and phrases reflected political systems are Peraturan Daerah, Peraturan Desa, and KUH Pidana. The morphemes and phrases denoted to economic condition are various punishments from Rp 50.000, Rp 200.000, Rp 250.000, Rp 500.000, Rp 5.000.000, and Rp 50.000 .000 .

\section{CONCLUSION}

There are three conclusions in this study. First, in Biological background, several morphemes that reflected biological condition in either biotic or abiotic components are found in aquaculture area, park, cemetery and housing. Second, the ideological background, the public sign that contained belief, myth, and paradigm in a society are found in housing, train station, park, river, gas station, cemetery, mosque and factory. Third, in sociological dimension, the morphemes and phrases contain various job, political system, status and economy in a society in Sidoarjo Regency.

\section{SUGGESTION}

As suggestion for further Ecolinguistic Study, the analysis of biological background, ideological background, and sociological background can be applied 
to analyze different object. It is to show the linguistics characteristic of particular area.

\section{REFERENCES}

Fill, Alwin and Peter Muhlhausler. "The Ecolinguistics Reader, Language, Ecology, and Environment". In Language and Communication. April 2004. Vol 24 No 2: 183-205.

Kurniawati, Wira. 2018. "Larangan Membuang Sampah: Potret Budaya Masyarakat Melalui Pemakaian Bahasa Indonesia di Ruang Publik. KBI. Oktober 2018.

Myers, Greg. 1994. Words in Ads. London: Edward Arnold.

Steffensen, S.V. 2007. Language, Ecology, and Society: An Introduction to Dalectical Linguistics. Chapter 1 in Bang, J.C. and J. Door: Language, Ecology, and Society- a dialectical approach. Ed. S.V Steffensen and J. Nash. London: Continuum.

Source from Internet: Government of Sidoarjo Regency, 2019. Geografis Kabupaten Sidoarjo. Source: http://www.sidoarjokab.go.id. Accessed on March 14, 2019 at 8.15 PM 